\title{
管理協定に見るオランダの農村資源管理政策
}

\author{
佐 藤 洋 平*
}

はじめに

農村の資源を保全管理するための政策手段の一 つに管理協定注1)(beheersovereenkomsten)をオラン タが導入したのはそう昔のことではない。近代化 された集約的高生産性農亲が自然の保鿁あるいは 累钼の保全との間に紫張関係を高じさせるように なった1970年代中頃のことである。「展業と自然 および景観保全との阅係についての白書」(nota betreffende de relatie tussen Landbouw en Natuuren

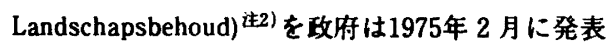
し，農村の自然等を保全することに对する国民の ニースと高生産性宸業の振興との間に調和を図る ための政策を打ち出した。管理協定はそのための 一つの政策手段としてそこで初めて位置つけけられ た。

管理協定の基本概念は英国において発達したと 言われている。1932年の「都市および田園計画 法」(Town and Country Planning Act 1932)の中 にそれは初めて取り入れられ，その後1949年の 「国立公園および田園活用法」(National Parks and Access to the Countryside Act 1949)の施行によ って英国で広く用いられるようになった。土地を ある特定の方法で管理することに地方政府と同意 した土地所有者はその補供として一定の金銭を受 領する，というのが英国におけるその基本概念で ある1。

生乳の過鄱供給に直面している E Cは1984年に 至り生乳出荷割当 (quota) 制を開始し，ECにお ける生乳の生産調整を強化した。宸地の約 $60 \%$ か
草地であり，そこに高度に集約された酷農経営が 展開されているオランタで，管理協定は生乳の生 産調整政策とのより強い結合のもとに，農村の桭 境资源保全政策と農業政策との而翼を担う重要な 政策手段として位圈づけられている。本模は慰村 の資源管理を考える上で興味深い一事例としてオ ランタの管理協定の現状について報告する。

\section{I 管理協定誕生の背景}

1950年代および60年代を通じた高度経済成長に よって農業は近代化され，機械化され化学化され た集約的曟業に変した。それをいくつかの指標に よって1950年と1980年との比較で見ると，1 ha当 たりの乳牛頍数は 1.6 倍に，年間 1 ha当たり牧草 生産量も1.6倍に，年間 1 ha当たりに投入される 窒素量は4.3倍に，年間 1 ha 当たりの生乳生産量 は2.4倍に增大していることが分かる2)。酪展に 見るこうした高度に集約された経営の展開は，そ の一方で，伝統的農業がその副産物として作りだ した，牧草地の合間に沼沢地が点在しそこには 種々の植物や野生の小動物が棲息しているといっ た，変化に富んでいる美しい農村詈観を破壊する こととなった。

高度释済成長がもたらした生活水滨の向上と余 壀時間の增大に伴い人々は自然を保讙し景観を保 全することに閉心を持ち，自然保諹や歴史的文化 的景锶の保全を求めるようになった。1960年代か

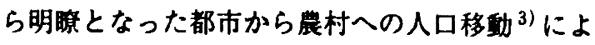
って農村社会は著しく変貌した。英国農村に見ら

\footnotetext{
* 筑波大学社会工学系 Inst. of Soc. Econ. Planng., Univ. of Tsukuba, Tsukuba 305. Japan.
} 
れた同様の変獍について農村社会学者ハワード・ ニュービイ (Howard Newby)は「田園は中産階級 の領土と化した」と述へている゙'が, オランタ宸 村社会のこうした「中産階級化」によって自然等 の保全に対する声が慰村の内部からも强く発せら れるようになった。そうした声の高まりを背景 に，農業活動に一定の制約を付したソーニングを 制定する市町村が多く現れ，自然保護のために農 地を取得する試みも多く見られたが，無補傥の規 制であったことや土地取得に对して晨家の抵抗に 直面したことなどから，十分な成果を上げること ができなかった。

1975年にオランタ政府は「関係白整」を発表す ることになるが、これに先立つ前年には「国立 公園白寒に関する规則」(Regering tegelijk met de Nota Nationale Parken) および「国立景観公園白 書」(Interimnota Nationale Landschapsparken) を 発表した注3)。農村の自然等保全に関する政策の第 一歩は，蕽業者以外の人々による農村空間の利活 用を最大限可能にすること，変化を受けやすい自 然嫄境を保全することを唱った農漁業大臣の1972 年予算説明の中に見ることができる

「関係白書」では農業と自然保護あるいは景観 保全との間に生している軋㷊を記述するととも に，そうした状況を改善するために農業地域，保 全地域あるいは环境变化を受け易い地域を指定 し，管理協定が莀家に容易に受け入れられるよう な手段を提示している。政策手段には，1）自然 等保全に関した管理協定，2）集約的裳業が不適 切な地域に対する特別措置， 3 ）同意に基づく特 別な自然の保護，4）同意に基づく固有累锶の保 全，5）農地集団化事業による自然の保護および 䍗観保全の推進の五つを挙げた ${ }^{6)}$ 。

「関係白書」の中で提言された管理協定を実施 するための手続き等を定めた「管理協定施行規 則」(Beschikking Beheersovereenkomsten) が1977 年に農漁業省によって出された。

農村の自然や景観を保全することが望まれる地 域の指定に際しては，異なる政策対応が伴う二種 類の地域に区別され指定される。一つは保荽区 (reservaatsgebied) としての地域指定であり, 自 然や景観を保護するために農業をいずれは止めな
ければならない地域である。農地管理局 (Bureau van Beheer Landbouwgronden) は所有者の自由意 思尊重のもとに宸地を取得し, 自然保誏団体がそ れを管理する。土地を農地管理局に缞渡しない宸 家は管理協定を結び自然や景観の保全を優先させ た土地利用を行う。もう一つの指定地域である管 理区 (beheersgebied) は農業地域ではあるが, 自 然や詈観を保全することも重要である地域で，晨 業と自然等保全とを而立させるための政策手段で ある管理協定が適用される地域である71.8)。

住宅・国土計画及び環境省 (Min. van Volkshuisvesting,Ruimtelijke Ordening en Milieubeheer) id 100,000haを保護区に，更に100,000haを管理区に 指定することを予定したが，財政事情により，当 面の目標値を両地域合わせて 100,000 ha としてい る。国は「関係白書」に唱われた政策手段を実施 する对象地域としてその中から優先性の高い地城 86,000 haのリストを州政府に提案した ${ }^{9}$ 。

これらの地域は保蓄区や管理区の指定による自 然保蓄や目観の保全が急がれている地域である。 残りの14,000haについては州政府の判断に委ねら れている。

\section{II 管理協定の内容}

管理協定は，農漁業省に設けられている宸地管 理局を主務機関とし，この展地管理局と宸家（地 主あるいは耕作者）との間で票地利用の方式につ いて取り交わされる任意の契約である。その内容 は，串村の自然を保護し景観を保全することを目 的に蕽地利用の方式を定めた管理計画 (beheers plan)に基ついた宸地の利用を行い，それに伴う 莀業所得の留失部分が補供される，というもので ある。

\section{1 管理計画}

保讙区や管理区が指定されると，農地管理州 委員会 (Provinciale Commissie Beheer Landbouw gronden) はそれら地域において宸業と自然等保全 との調和を図るための管理計画を作成する。この 計画では，地域のどんな自然や景観を保護・保全 
すべきか、そのためにどの様な管理をすべきか， そうした管理を行うことによって減少する所得に 对してどのくらいの補供をすべきか，などが定め られる。

保護・保全の対象となるものは地域ごとに異な ク，それが野生動植物の保蓄であったり，森林や 自然地域の周辺の農地を紘衙地带として管理する ことであったり，堤の並木や池沼等景観要素を保 全することであったりする。

それぞれの地域の状況，すなわち自然，景観あ るいは農業の状況に柔軑に対応できるように管理 行動についていくつかのパッケイジが用意されて いる。例えば，放牧地に棲息するある種の鳥を保 譂するために牧草の刈り取りの開始時期や耕作方 法を定めたり, ある種の植物の保護が重要な地域 では化学肥料や農薬の使用を抑制した行動体系が 数種類のパッケイジとして定められる。

管理協定に関する補償のために，管理協定を実 施する地域と類似した農業経営地域で管理計画の 対象ではない地域を近傍から選び, 比較地域とす る。この比較地域と管理計画区域とを比較するこ とによって管理協定の有無と経営構造や経営内容 の変化の関係を明らかにし, 収益, 國場作業に要 した追加的労陲，作業費などを計測する。管理協 定実施の宸家の所得が比較地域の農家の所得と較 ベて下回らないということが補哄の基本姿㢣とな っている。

以上を要約すると管理計画は以下の五つにまと められる。

1）地域の野生動物等自然や累観を記述し評価 し，その中の何を保荠・保全の対象とするかを 特定する，

2）上記対象を保誩・保全するために農家がとる べき管理行動体系のパッケイジを定める,

3）似たような農業経営が行われている近傍の類 似地域から比較地域を選定する，

4）計画地域と比較地域とについて, 農業経営条 件, 経営内容等について詳述する,

5）管理協定に伴う補偵の水準を明らかにする。 農地管理州委貝会は農業団体, 自然保誸団体, 国，州，市町村および水管理組合 (Waterschap) の 代表功構成される。同委員会によって作成され
た管理計画は公聴会に付され意見聴取の後, 農地 管理中央委員会 (Centrale Commissie Beheer Landbouwgronden)によって決定される。

\section{2 管理行動体系}

保護区あるいは管理区における農地管理の基準 として, 保護・保全の対象に対応してどの様な作 業体系でどの様な水準の管理行動をすべきかにつ いて管理行動体系が作成される。

放牧地に棲息する野鳥および多様な植生を保詨 することを目的とする管理区での管理条件を例示 するならば以下の通りである ${ }^{9)}$ 。

1）現状の高い地下水位を維持する,

2）牧草地の耕起を行わない,

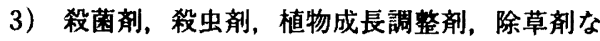
ど宸薬の使用は局部的にする，

4）八ローによる耕作は 4 月15日から 6 月15日の 期間に行う，

5） 4 月15日から 6 月15日の期間には牧草の刈り 取りも放牧も行わない,

6） 4 月15日から 6 月 15 日の間は黄尿散布を行わ ない。

これらの管理条件について，その中のどの条件

とどれとを組み合わせた農地管理を行うかについ て, 農家は自己の農業経営との関わりで最も適切 な選択を行えるように，管理行動体系がいくつか のパッケイジとして用意される。表 1 にそのパッ ケイジの一例を揭げる。

こうした管理行動体系は，その基本要件とし て, 目観の保全にも寄与すること, 管理行動体系 のもとでの農業が実施可能であるばかりでなく技 術的にも経済的観点からも実行性あるものである こと，補償費用と㻴境保全効果との均衝がとれた ものであること，実施が容易であることなどを具 備していることが求められる。

\section{3 管理協定の実施}

管理計画が確定された後に，農家の自由意思に 基づいて管理協定の契約は農地管理局と結ばれ る。どの様な農地管理を行うかについては，農家 はパッケイジ化された管理行動体系の中から自分 に適したものを選択することができる。管理区あ 
表 1 管理協定による管理行轩体系の一例

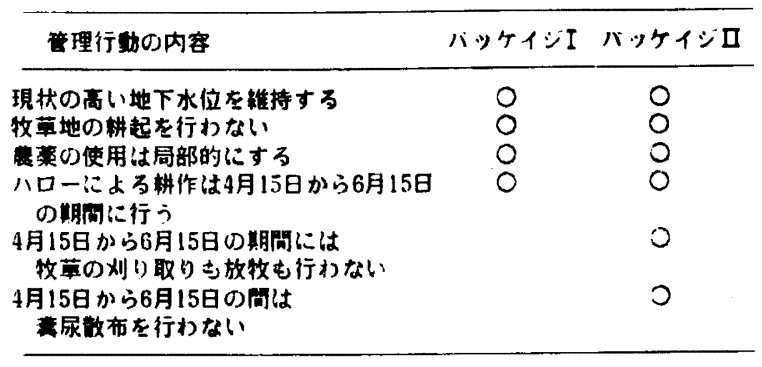

出典: 文狱9)より作成。

るいは保函区にある所有地あるいは耕作地の全て について管理協定の契䄪を結ぶのか，おるいはそ の一部だけにするかについても展家は任意に選択 できる。

管理協定の契約を結ふ時期は年に 4 回設けられ ている。この契約は管理計画の確定後 6 年間奻力 を有するので, 計画確定後直ちに管理協定の契約 が結ばれる場合には最長 6 年間が契約期間とな ク，計画確定後数年を経て契約が結ばれる場合に は残余の期間が契約期間となる。期間が满了した 後の処置については，終了することについての意 思表示がない限り，契䄪は更に 6 年間自動継続さ れる。これとは別に，管理協定締結後の初の 1 年間は試行期間として位直づけられ，1 年経過後 に契的を破米する自由が展家に与えられている。 このプログラムが始められてから今日までのとこ ろ，1 年後の契約破柬の事例は極めて少ない。農 地管理局は保讙区の土地については取得を目的と するが管理区については土地取得を目的としな い。しかし，農家がなんらかの理由によって管理 協定の契䄪を䊅んだ展地を売却する時，家族柈成 員に鿁渡する場合を除き，宸地管理局がその展地 の買い取りについて優先権を持つ。同管理局がこ の権利を行使しない時は第三者に譲渡できるが， その晨地に買い手がつかない場合には，同管理局 はそれを買い取らなければならない。この展地は 管理計画で展地利用上一定の制約が付されている が,そうした制約がないもとでの農地価格水华で 買い取られる。これは，管理協定の契約を結ぶこ とによってあるいは保讙区に含まれることによっ
て宸地の価格が低下し，そのことによって擘地所 有者が不利益を被ることを回避するための措置と なっている。自作地以外の层地について管理協定 の契的を結ぶ場合は耕作者と土地所有者の而者か その契約を詰ばなければならない。展地価格が低 下することを恐れて土地所有者はこうした契䄪締 䊅に消極的になる㑯向がみられるが，上記展地価 格に対する保証措置はそうした不安を解消するも のといえよう。

なお，管理協定の契約が結ばれた展地を第三者 が取得する場合，取得者はその管理協定を継承す る義務を負う。

\section{4 管理協定補俗}

管理区あるいは保譆区では自然あるいは贯锶の 価值を保讙することが優先されるが贯家の利益も 保詳する必要があり，自然あるいは褁篗の価值を 保荠しつつ晨家の利益を保讙するための措異とし て管理協定に伴う載俊が用意されている。

補供には四つのタイブがあるが主要なものは以 下の二つである。

1）管理補供：これは管理協定に基づく管理行動 体系を実施することによって生じる所得の装失 に対して補償するものである。この補仯に際し ての基本原則は，管理協定に参加する跟家の所 得がそれと類似の展業来件のもとで管理協定に 参加せずに宸業释営を行う農家の所得より下回 らないことを保証することである。 この基本原則に基づいた補僙を行うためには， 管理区と農業条件の類似する嗃切な比较地域を 
設定することが求められる。管理協定に基づく 管理行助体系を実施することによって農業経営 状況が比较地域ととの位相逜するのか，その相 違す万程度によって補僙䫓は定められる。管理 行動体係の実施は収量の減少, 作業労㑬の增加 およびその他生産费の增大あるいは減少を伴 う。これら三つの要素が補供額の算定の根揵と なる。㭪供額は每年物価指数に合わせて調整さ れる。

2）道応補供：これは従前の農菜経営を管理協定 下の展業経営に適応させるために負担すること になる翼用を補供するものである。従前の状況 に较へてどの位生産水準が低下したか, 、従前に おける层業経営の集約性水隼はどの程度であっ たかということがこの補借の算出基礎となる。 管理補供と異なりこの補虽は贯家一戸一戸につ いて算定される。

管理協定によって引き起こされる施設や装偖の 遊休化等がこの補偵の対象となる一例である。 この補供の性格から容易に推察されるように， これは一時的なもので，補供期間が最も長い場 合でも18年間であり，補供額は年ごとに低減す る。

以上の外に，地主に対する禣供がある。管理協 定の結果, 地代が比較地域の地代よりも低くなっ た場合に行われるもので，この補供顧は当該の管 理補供分から差し引かれる。管理区の指定が外さ れることによって管理協定の契約が終結させられ る場合にも補供が行なわれる。従来の農業経営に 復帰するために要する期間に対する補供である が、現在までの所この種の補借の必要性は生じて いない。

表 1 に揭げた管理行動体系のうちのパッケイジ 2 を探用した㖘地管理を実施する場合を事例に挙 げて㭪供の概要を以下に説明する9)。

\section{A. 管理補倓}

1）収量の減少について：生乳の減産は2,100 KVEM/ha と注4) と見皘られる。それに伴う収

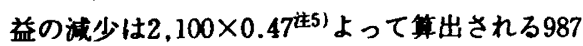
ギルター（1 ギルターー=約63円 $)$ である。

2）作業労㑬の増加について：除草郕などの農薬 の使用を局部的にすることによって余分にかか
る労働量は 1 時間／haであり，これに時間当り の労働費を掛けて求められる労働费の增加䫫は

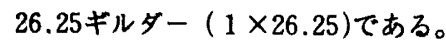

3）その他の生産糞について: 牧草の刚り取り時 期や放牧時期の限定に伴う窒素肥料投入の娍少 は $120 \mathrm{~kg} / \mathrm{ha} て ゙, 1 \mathrm{~kg}$ 当りの価格1.5ギルターを 掛け合わせた180ギルター/haが隇少する。い くつかの耕作作業を実施しないことにより浮く 作業费用（然料费，労倠费等）が60ギルダーノ ha。農業生産に必要な農地管理が減少すること により浮く費用か50ギルター/ha。

一方，算尿散布が制限されることにより必要と なる樭尿貯蔵施設费が78キルタター／ha增加す る。

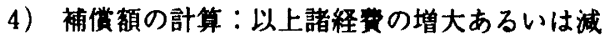
少を加減算して補償頪が算定される。

$987.00+26.25-180.00-60.00-50.00+78.00$ $=801.25$ ギルター

これが 1 年間に支払われる 1 ha当りの補暴額で ある。

B，適応補偵

管理協定を実施する以前の状況では4,410KVEM /haの水蕉の生産が行われていたが, 実施後に 1,160KVEM/haの減産がみられたことを想定 するならば, 従前の状況で 1 ha当りの乳牛飼育 単位か52.5の飼育密度である場合には，適応補 供額として383ギルター/haが見積られる。1.5 単位の場合には78ギルダー/haである。

\section{III 国土計画との関係}

オランタにおける国土計画の体係は1962年に制 定された「国土計画法」(Wet op de Ruimtelijke Ordening)に基づいて構成される。国は国土政策 を立て，州は州域内を対象に国土政策に整合した 地域計画を立てる。市町村はこの地域計画に整合 する土地利用計画を策定するが，それは構造計画 (structuulplan) と配置計画 (bestemmingsplan) の二 つの計画から成る。配置計画は詳細に描かれたソ ーニングであり，土地利用に係わる私権を制限す る。 


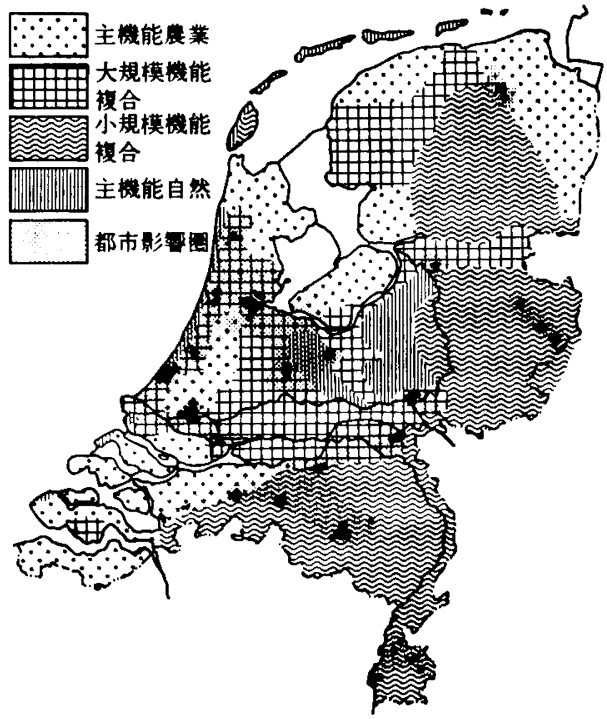

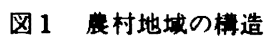

管理計画はこうした国土計画の体系とは別に独 自の計画として立てられる。市町村が策定する土 地利用計画は土地の利用に関して万人が強制され ろ計画制限を具備しているのに较へ，管理計画は 宸家の自由な意思と自発性を基本に構成され，管 理協定への宸場の参画を促進することを狙いとし た計画である。

管理計画は国土計画の体系とは直接の関係を持 たないとは言え「関係白费」に唱われた宸村地 域に関する基本姿勢は，「第三次国土計画白書」 (de Derde Nota over de Ruimtelijke Ordening) 三 分冊の一つとして1977年に出された第三分冊「農 村地域白春」(Nota Landelijke Gebieden)に反映 され，国土の自然や目観を保護・保全するための 政策手段としてそれは位置づけられていることは 言うまでもない。この白串は農村地域を農産物の 生産地域として単に位置づけるばかりでなく，都 市型社会への移行に伴って自然, 景観あるいは野 外レクリエーションにとっても重要な意味を持っ 空間であると位圈づけている。そして，相反する 利害を調整しながらそうした多様な農村㞬間の役 割を引出す蕽村政策を進めるためにその基準とな
る地域区分を提示している。それは図 1 に見るよ うに農村地域をそれぞれの地域の主要な機能を評 価することによって五つに区分したものであり， そのそれぞれの区域について政策の方向を示して (ろ10)。

図中の「A」区域は宸業が地域の主要な機能で あり，政策の第一目的が農業の振興等展業の利益 を守ることにある区域として定められる。「B」 区域は蕽業以外の比較的大规模な機能と農業とが 混在している地域で, それぞれの地域の状況に照 らして農業、レクリエーションあるいは自然保全 が最も重要となる区域である。「C」区域は農亲 および自然とその他の比較的小规模な機能とが混 在する地域で，農業との利害を調整しつつ鬿力的 で多様な景観の保全が優先される区域として位置 づけられる。自然が地域の主要な機能である「口」 区域は自然保護が優先されるが，農業やレクリエ ーションがそれに次いで重視される区域である。 都市图の影㸷下にある「E」区域ではまだ都市化 されていない景観を保全することによって地域の 多様性を確保したり,レクリエーションの機会を 創り出すことが主要な政策課題である。

昨年（1987）年に「第四次国土計画白春」が新 たに出されたが，農産物の供給過剩基調を背景 に，この白㫪は貫村地域が担うべき機能としてレ クリエーション，自然および景観により一層の重 要性を与えている。

\section{IV 管理協定の実施状況}

1980年に北ブラバント州 (Noord-Brabant) のオ イルスホットベスト (Oirschot-Best) で管理計画が 最初に立てられて以後 7 年が経過した1986年現在 までの管理計画の実施状況を表 2 に揭げる。保護 区あるいは管理区として指定された $40,631 \mathrm{ha}$ の地 域に67の管理計画が，その指定地域の63\%を对象 に，立てられている。指定地域の内 $3,601 \mathrm{ha}$ の土 地は保讙区として農地管理局によって取得されて いるので，管理計画区域の残り21,998haが管理協 定の対象となる土地であるが，その $29 \%$ の土地に 管理協定が実施され8900展場がそれに参加して 
表 2 管理計画の実施状況

（1986年12月31日現在）

\begin{tabular}{|c|c|c|c|c|c|c|c|c|c|}
\hline \multirow[b]{2}{*}{ 年沵。 } & \multicolumn{3}{|c|}{ 管理㖕画 } & \multirow{2}{*}{ 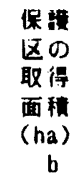 } & \multicolumn{5}{|c|}{ 管理協定 } \\
\hline & $\begin{array}{c}\text { 指定地域 } \\
\text { O)面桹 } \\
\text { (ha) }\end{array}$ & $\begin{array}{l}\text { 垶画 } \\
\text { 区域 } \\
\text { 心数 }\end{array}$ & $\begin{array}{l}\text { 計画区域 } \\
\text { の面稍 } \\
\text { (ha) } \\
\mathrm{a}\end{array}$ & & $\begin{array}{c}\text { 面积 } \\
\text { (lia) } \\
c\end{array}$ & 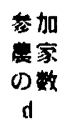 & $\frac{b+c}{a}$ & $\frac{c}{a-b}$ & $\frac{c}{d}$ \\
\hline $\begin{array}{l}1981 \\
1982\end{array}$ & $\begin{array}{l}19.723 \\
24.685\end{array}$ & $\begin{array}{r}9 \\
16\end{array}$ & $\begin{array}{l}5.743 \\
7.056\end{array}$ & $\begin{array}{l}500 \\
878\end{array}$ & $\begin{array}{r}967 \\
1.205\end{array}$ & $\begin{array}{r}72 \\
108\end{array}$ & $\begin{array}{l}26 \\
30\end{array}$ & $\begin{array}{l}18 \\
20\end{array}$ & $\begin{array}{l}13.7 \\
11.2\end{array}$ \\
\hline 1983 & 26.413 & 28 & 15.627 & 1.726 & 2.947 & 290 & 30 & 21 & 10.2 \\
\hline 1984 & 29.399 & 37 & 18.961 & 2.172 & 3.682 & 415 & 31 & 22 & 8.9 \\
\hline 1985 & 34.333 & 48 & 20.769 & 2.904 & 4.661 & 611 & 36 & 26 & 7.6 \\
\hline 1986 & 40.631 & 67 & 25.599 & 3.601 & 6.334 & 890 & 39 & 29 & 7.1 \\
\hline
\end{tabular}

出典：文献12)\&!作成。

表 3 管理計画の州別実施状況

（1985年3月31日現在）

\begin{tabular}{|c|c|c|c|c|c|c|}
\hline 州 & 計画対象・ & $\begin{array}{c}\text { 笶理㖕画 } \\
\text { 面积( ha) } \\
\text { a }\end{array}$ & $\begin{array}{c}\text { 保謨区取 } \\
\text { 得面科(ha) } \\
\text { b }\end{array}$ & $\begin{array}{c}\text { 面䖽 (ha) } \\
\text { c }\end{array}$ & $\begin{array}{l}\text { 管理協定 } \\
\frac{b+c}{a}(i)\end{array}$ & $\frac{c}{a-b}\left(\begin{array}{l}4 \\
(4)\end{array}\right)$ \\
\hline Groningen & k & 669 & 65 & 158 & 33 & 26 \\
\hline Friesland & w & 3.385 & 125 & 837 & 28 & 26 \\
\hline Drenthe & 0 & 1.901 & 108 & 101 & 11 & 6 \\
\hline Overijssel & v & 2.070 & 306 & 608 & 44 & 34 \\
\hline Gelderland & $w / 0$ & 625 & 39 & 40 & 13 & 7 \\
\hline Utrecht & $w$ & 734 & 84 & 35 & 16 & 5 \\
\hline Noord-Holland & $w$ & 5.242 & 746 & 1.914 & 51 & 43 \\
\hline Zuid-Holland & $w$ & 1.551 & 197 & 39 & 15 & 3 \\
\hline $\begin{array}{l}\text { Zeel and } \\
\text { Noord-Brabant. }\end{array}$ & $\begin{array}{l}w \\
n\end{array}$ & $\begin{array}{r}667 \\
1.924\end{array}$ & $\begin{array}{l}172 \\
242\end{array}$ & $\begin{array}{l}44 \\
85\end{array}$ & $\begin{array}{l}32 \\
17\end{array}$ & $\begin{array}{l}9 \\
5\end{array}$ \\
\hline $\begin{array}{l}\text { Limbrug } \\
\text { 全地域 }\end{array}$ & 0 & $\begin{array}{r}1.290 \\
20.058\end{array}$ & $\begin{array}{r}88 \\
2.172\end{array}$ & $\begin{array}{r}122 \\
3.983\end{array}$ & $\begin{array}{l}16 \\
31\end{array}$ & $\begin{array}{l}10 \\
22\end{array}$ \\
\hline
\end{tabular}

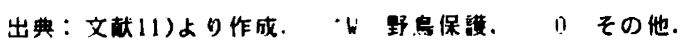

いることがこの表より読み取れる。既に取得され た保讙区の面積と管理協定面積とを合わせると， 管理計画区域の38.8\%において自然等を保護・保 全するための行為が行われている。指定地域に対 するその割合は24.5\%であり，目標の約四分の一 が達成されたことになる。生乳のクオー夕制が開 始された1984年の前年には管理協定への参加麇場 数も参加面積もその前の年の2.5倍にも達する水 準に一举に増加しているが，その後の最近の傾向 を見ると，参加展場数は毎年 $50 \%$ 弱の增加率を持 続し, 参加面積の增加率は年々增大する傾向を示 していることから政府の当面の目標達成はそう遠 いことではないことを窺わせる。
管理計画の区域面積の大きさを1985年 3 月末現 在までの管理計画について見ると，最も小さい35 haのものから最も大きい3,747haのものまで，大 きな開きがあるが, 平均すると約 $500 \mathrm{ha}$ の規模と なっている。管理計画をその対象によって，牧草 地に棲息する野鳥の保荄 (weidevogelbeheer) とそ の他のもの（主たる対象が植物の保荄であったり 緩街緑地の管理などなど）とに分けと，管理計画 が策定されている区域全体の73\%が野鳥保護を対 象とするもので占められ, 残り $27 \%$ かその他のも のである。前者の計画区域の大きさの平均は583 ha, 後者は366haで計画区域の大きさが計画の対 象によって相違していることが分かる。また，管 
理協定の実施状況が計画全体では22\%の段階で, 前者が $28 \%$ と平均よりやや高いのに較べ後者は 6 \%と低い実施状況にとどまっている。

管理協定への農場の参加状況を州別および計画 の対象別に整理したものが表 4 と表 5 である。

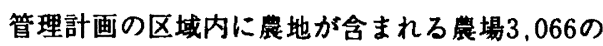
内, $481(16 \%)$ の農場が管理協定を結んでいる。 北ホラント (Noord-Holland), オーフェレイセル (Overijssel), フローニンダン (Groningen) の諸州で 高い実施事を示しているのに較へ、南ホラント (Zuid-Holland), ドレンテ (Drenthe), 北フラバント (Noord-Brabant). およびリンフルフ (Limburg)の 諸州では10\%の水準にも到達していない。前者の クルーブは 3 州だけで管理協定締結展場総数の56 \%を占めている。管理協定参加農場の管理計画区 域内に含まれる宸地面皘は平均 $9.3 \mathrm{haで，これは}$
農場の平均規模の約 $50 \%$ に相当する。その展地面 積の $89 \%$ に相当する平均 $8.3 \mathrm{ha}$ の宸地が管理協定 の対象となっている。

管理計画の対象別にみると，野鳥保護を対象と する管理協定参加農場率は $28 \%$ ，その他のものへ の参加晨場害は $6 \%$ であり, 面稓についての前述 の構成割合と全く同じ値を示している。野鳥保護 を対象とする管理協定参加晨場はその管理計画区 域内に平均 $11.0 \mathrm{ha}$ の展地をもち, そのうちの 9.8 ha $(89 \%)$ の宸地が管理協定の対象となってい る。一方，その他の管理協定では，それぞれ3.7 ha, 3.0ha (81\%) であり，野鳥保護の場合のそ れぞれ三分の一に相当するにすぎない。管理目的 の遑いによるこの相違は，野鳥保護を対象とする 管理計画は農場規模の比較的大きな地域で立てら れているのに較へ，その他の管理計画は農場規模

表 4 管理協定参加鹿場数の州別状況

（1985年3月31日現在）

\begin{tabular}{|c|c|c|c|c|c|c|}
\hline 名 & 実数 & 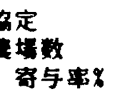 & $\begin{array}{c}\text { 㖕画 } \\
\text { 阅任 } \\
\text { 実数 }\end{array}$ & 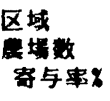 & 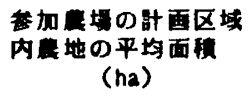 & 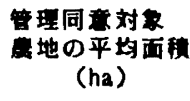 \\
\hline Groningen & 23 & 5 & 56 & 2 & 10.3 & 6.9 \\
\hline Frjesland & 53 & 11 & 237 & 8 & 17.0 & 15.8 \\
\hline Drenthe & 27 & 6 & 721 & 24 & 3.4 & 3.2 \\
\hline Overi jssel & 110 & 23 & 239 & 8 & 6.8 & 5.5 \\
\hline Gelderland & 20 & 4 & 189 & 6 & 3.4 & 3.2 \\
\hline Utrecht & 15 & 3 & 67 & 2 & 2.4 & 2.4 \\
\hline Noord-Holland & 135 & 28 & 289 & 9 & 15.0 & 14.2 \\
\hline Zuid-Holl and & 7 & 1 & 239 & 8 & 6.3 & 5.6 \\
\hline Zeeland & 17 & 4 & 106 & 3 & 3.4 & 2.6 \\
\hline Noord-Brabant & 33 & 7 & 415 & 14 & 2.8 & 2.6 \\
\hline $\begin{array}{l}\text { Li iburg } \\
\text { 全地城 }\end{array}$ & $\begin{array}{r}41 \\
481\end{array}$ & $\begin{array}{r}9 \\
100\end{array}$ & $\begin{array}{r}508 \\
3,066\end{array}$ & $\begin{array}{r}17 \\
100\end{array}$ & $\begin{array}{l}4.4 \\
9.3\end{array}$ & $\begin{array}{l}3.0 \\
8.3\end{array}$ \\
\hline
\end{tabular}

出典：文封11)より作成.

表 5 管理計画の对象別に見た管理協定参加㫳場の状況

（1985年3月31日現在）

\begin{tabular}{|c|c|c|c|c|}
\hline 笛理壾而 & 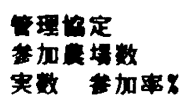 & 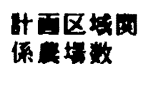 & $\begin{array}{c}\text { 内加地の平均面积 } \\
\text { (ha) }\end{array}$ & $\begin{array}{l}\text { 理定新的 } \\
\text { (ha) }\end{array}$ \\
\hline 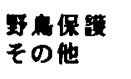 & $\begin{array}{l}372 \\
109\end{array}$ & $\begin{array}{l}1,336 \\
1,730\end{array}$ & $\begin{array}{r}11.0 \\
3.7\end{array}$ & $\begin{array}{l}9.8 \\
3.0\end{array}$ \\
\hline 全体 & 481 & 3,066 & 9.3 & 8.3 \\
\hline
\end{tabular}

出典：文部11)より作成。 
の小さい地域で着手されていることが反映された 結果である。

最後に管理協定の澌を管理水望の高低注6)という 梘点からみると，野鳥保護を对象とする管理の場 合63\%の宸場が, その他の場合も60\%の宸場が, 高い（あるいは群しい）管理水準を実施している 農場に該当し，管理の質の管理目的による違いは 見られない。

\section{おわりに}

本稿は都市型社会を迎えたオランタの国土政策 を背景に現在進められている晨村地域政策の中か ら管理協定を取り上げて論じたるそれは「関係白 春」に基づく政策の根幹を成すものであり，E C における農産物の過剩供給の問題とも関連して, 従来の「選択的成長」政策の延長線上に位置づけ ることもできる。

これを環境政策の中にも位䁂づけることは当然 に可能であるが，農業政策が孯観を含めた意味で の地域瑔境保全に関わる政策を取り込んでいるこ とに刮目する必要がある。実施後 6 年を释過した 時点で行なった管理計画の評価は, 年間 1 ha 当り 750ギルターという平均補偵䭭を投したことによ って牧草地に棲息する野鳥の数が，増大している とまでは言えないが，少なくとも安定してきたと いう結果を明らかにしている12)。

本稿は1986年 6 月末より 1 年余り客貝研究員と してオランタ国立研究所 I CWに滞在した期間に 得られた知見をもとにしている。Dr.L.M.van den Berg, IngJ.B.Sprik はじめICW の同僚研究員諸氏 の協力に謝意を表する。

また，锠切かつ有益なコメントを頂いた査読委 貝諸氏に深甚の謝意を表したい。

\section{注}

注1) オランダ語の overeenkomsten は英語の agreementsに相当し，本䄸では一般的訳語に做い 「協定」と訳す。
注2）一般には「関係白莗」(Relatienota) と呼び慣わ されている。

注3）これら三つの白書をあわせて「緑の白㫪」(gro ene nota's) と呼ばれている。

注4）KVEM は飼料 $1 \mathrm{~kg}$ 当りの泌乳年を表わす単位。

注5）1987年時点での価格水草を表わす。以下も同様。

注6）管理目的によって管理行動体系は異なるので管 理水望の高低を一元的には定余できないか，管 理行動体系のパッケイジを判断根拠とする。例 えば野鳥保淁を管理目的とする場合，その年の 最初の牧草刘り取りあるいは放牧を 6 月 1 日以 啳に行なうことを定めたバッケイジを管理水篗 の高いものといい，それ以外のパッケイジは低 い管理水望のものと判断される。

\section{考文献}

1) Blacksell, M. \& Gilg, A. (1981) : The Countryside, George Allen \& Unwin. pp. 209-210

2) Landbouwcijfers, Landbouw-Economisch Instituut en Centraal Bureau voor de Statistiek.

3) Statistisch Zakboek, Centraal Bureau voor de Statistiek.

4) Lowe, P., Cox, G., MacEwen, M., O'Riordan, T. \& Winter, M. (1986) : Countryside Conflicts, Gower, p. 23.

5) Kramer, Q. J. M. (1985) : Landinrichtingswet, Tjeenk Willink, p. xi.

6) de nota betreffende de relatie tussen Landbouw en Natuur en Landschapsbehoud, 1975.

7) Beschikking beheersovereenkomsten, 1977.

8) Toelichting op voorontwerp (concept 26-10-'84), Wet Beheer Landbouwgronden, mimeo.

9) Min. of Agr. \& Fish. (1987) : Management agree ments in Dutch agriculture.

10) Nota Landelijke Gebieden, 1977.

11) Boelen, J. (1986) : Beheersovereenkomsten in het landelijk gebied, Cultuurtechnish Tijdschrift 25 (6). pp. $389-400$.

12) de Boer, T. F. and Reyrink, L. A. F. (1987):THE POLICY CONCERNING THE RELATIONSHIP BETWEEN AGRICULTURE AND NATURE CONSERVATION IN THE NETHERLANDS, mimeo. 